\title{
Copper(II) Interaction with the Human Prion 103-112 Fragment - Coordination and Oxidation
}

\author{
Gizella Csire $^{a}$, Lajos Nagy ${ }^{b}$, Katalin Várnagy ${ }^{a}$ and Csilla Kállay ${ }^{{ }^{*}}$ \\ ${ }^{a}$ Department of Inorganic and Analytical Chemistry, University of Debrecen, $\mathrm{H}-4032$ \\ Debrecen, Hungary \\ ${ }^{b}$ Department of Applied Chemistry, University of Debrecen, H-4032 Debrecen, Hungary \\ ${ }^{c}$ MTA-DE Homogeneous Catalysis and Reaction Mechanisms Research Group, \\ University of Debrecen, H-4032 Debrecen, Hungary
}

\begin{abstract}
The prion protein (PrP) is a membrane-anchored cell surface glycoprotein containing 231 amino acids. It has been associated with a group of neurodegenerative disorders. Copper(II) interaction with the Human Prion 103-112 fragment and its mutants has been studied with various techniques. The studied human prion fragment contains both histidine and methionine residues, while methionine residues are systematically replaced or displaced in the studied mutants. pH-potentiometric, UV-vis and circular spectroscopic techniques were applied to study the stoichiometry, stability and structure of the copper(II) complexes, while HPLC-MS and MS/MS were used for identifying the products of copper(II) catalyzed oxidation. The complex formation reactions of the studied ligands are rather similar; only 1:1 complexes are formed, where the imidazole nitrogen of the histidine residue is the main binding site beside the amide nitrogens of the peptide chain. The only difference is, that in the peptides which contain methionine in position 109 , in addition to the $\left(\mathrm{N}_{\mathrm{im}}, \mathrm{N}^{-}, \mathrm{N}^{-}\right)$coordination mode, a weak interaction of thioether sulfur atoms can be supposed. The mutant peptide which does not contain methionine did not undergo oxidation, only the fragmentation of the peptide chain was perceived. However, in the case of methionine containing peptides, the peptide chain was not cleaved; but the oxidation of methionine to methionine sulfoxide occurred.
\end{abstract}

\section{Introduction}

\footnotetext{
* Corresponding author

E-mail address: kallay.csilla@science.unideb.hu

Fax: +36 52518660
} 
The prion protein (PrP) is a membrane-anchored cell surface glycoprotein containing 231 amino acids. It consists of a helical C-terminal domain (residues 121-231) and a flexible and largely unstructured N-terminal domain (residues 23-120) [1,2]. It has been associated with a group of invariably fatal neurodegenerative disorders called transmissible spongiform encephalopathies (TSEs) which affect both humans (e.g. Creutzfeldt-Jakob Disease, Gerstmann-Straussler-Scheinker Syndrome, Fatal Familial Insomnia, Kuru) and animals (e.g. Bovine Spongiform Encephalopathy, Chronic Wasting Disease, Scrapie). Prion diseases may present as genetic, infectious, or sporadic disorders, all of which involve modification of the prion protein. The normal, cellular $\operatorname{PrP}$, denoted $\mathrm{PrP}^{\mathrm{C}}$, is converted into scrapie $\operatorname{PrP}\left(\operatorname{PrP}^{\mathrm{Sc}}\right)$ through a process whereby a portion of its $\alpha$-helical and coil structure is refolded into $\beta$-sheet [3]. This structural transition is accompanied by profound changes in the physicochemical properties of the PrP. PrP is most abundant in the central nervous and immune systems, but it is also expressed in other biological compartments [4]. Its physiological function has not been determined yet $[5,6]$. However, the property of $\operatorname{PrP}^{\mathrm{C}}$ to bind $\mathrm{Cu}(\mathrm{II})$ ions in vivo and in vitro suggests that its function relates to copper homeostasis or to copper-dependent enzymatic functions [7,8]. Several reports can be found about the binding affinity of copper(II) ions to PrP. There is a general consensus about that PrP can bind at least six copper(II) ions; four copper-binding sites are present in the octarepeat region (residues 60-91), and the region between the octarepeat and the C-terminal structured domain (residues 90-126) provides two further copper(II) binding sites, each associated with a histidine residue [9]. All these binding sites are taking part in the coordination of copper(II) ions in equimolar solutions, which results in the formation of coordination isomers. However, these binding sites are not equivalent; the predominance of the isomer with His111 binding is obtained [10]. The presence of Met109 residue in the vicinity of His 111 may contribute to the enhanced stability of these species. A weak interaction between the thioether function of Met109 residues and copper(II) ions is suggested.

In addition to the complex formation, the metal ions and their small molecule complexes can play an important role in various oxidative reactions of peptides. Metal catalyzed oxidation (MCO) is a hallmark of oxidative stress and accompanies biological aging and neurodegenerative diseases such as Alzheimer's and Parkinson's disease [11]. Accordingly, the coordination of copper(II) ion toward PrP is extensively studied, however the copper catalyzed oxidation of prion protein is the central question in several researches.

The investigation of metal ion catalyzed oxidation is a rapidly growing area in the coordination chemistry of peptides, the significance of these reactions is especially important 
in the understanding of the mechanism of various neurodegenerative disorders. Curtain et al. suggested that metal ions play a pivotal role in the generation of reactive oxygen species (ROS) [12]. The oxidative modification of specific amino acid residues in proteins may lead to loss or gain of function, changes in protein conformation and turnover and/or proteinprotein interactions. The metal ion-catalyzed oxidation of biomolecules involves reduction of $\mathrm{Fe}(\mathrm{III})$ or $\mathrm{Cu}(\mathrm{II})$ by a suitable electron donor such as NADH, NADPH, ascorbate or thiols. $\mathrm{Fe}(\mathrm{II})$ and $\mathrm{Cu}(\mathrm{I})$ ions bound to specific metal-binding sites on proteins react with hydrogen peroxide to generate hydroxyl radicals. These free radical generating systems can be replaced by $\mathrm{Cu}(\mathrm{II}) / \mathrm{H}_{2} \mathrm{O}_{2}$ [13-15]. MCO of proteins is mainly a site-specific process in which only one or a few amino acids at the metal-binding sites of the protein are preferentially oxidized $[15,16]$. Histidine and methionine are important targets of protein oxidation. 2-oxo-histidine was found to be the predominant product of MCO in histidine containing proteins such as human growth hormone [17] and human relaxin [18]. Other unidentified protein degradation products have been detected [18], including the formation of asparagine and/or aspartyl from histidyl residues $[19,20]$, Met $(\mathrm{O})$ (methionine sulfoxide) is proposed to be the major product of MCO of methionine [21]. Higher oxidized products of methionine may have an additional oxygen at the sulfur atom or at one of the carbon atoms, or addition of a perhydroxyl group $(\mathrm{OOH})$ at the sulfur atom $[22,23]$. The oxidation of protein may also lead to cleavage of peptide bonds. Scheme 1 presents the peptide fragmentation notation. Peptide fragment ions are indicated by $a, b$, or $c$ if the charge is retained on the N-terminus and by $x, y$ or $z$ if the charge is maintained on the $\mathrm{C}$-terminus. The subscript indicates the number of amino acid residues in the fragment [24].

One possible way to understand these very complicated metal ion-protein interactions is the study of the interaction of copper(II) ions with the short fragments of PrP. In this paper we report the synthesis and the studies of the interaction of copper(II) ions with the $\mathrm{HuPrP}(103-112)$ fragment (Ac-SKPKTNMKHM- $\mathrm{NH}_{2}$ ) and its mutants, including both coordination and oxidation. Methionine residues are systematically replaced with alanine (Ac-SKPKTNAKHA- $\mathrm{NH}_{2}$, Ac-SKPKTNAKHM- $\mathrm{NH}_{2}$ and Ac-SKPKTNMKHA- $\mathrm{NH}_{2}$ ) or displaced (Ac-MKPKTNAKHA- $\mathrm{NH}_{2}$ ) in the studied decapeptides The studied HuPrP fragment contains the -MKHM- sequence which has determent significance in the copper(II) ion binding, and the oxidation of histidine and methionine residues can be followed simultaneously in it. On the other hand, the replacement and displacement of methionine residues help us to clarify the role of methionine residues in these processes. 


\section{Materials and methods}

\subsection{Chemicals}

Chemicals and solvents used for synthetic purposes were purchased from commercial sources in the highest available purity and used without further purification.

All N-fluorenylmethoxycarbonyl (Fmoc)-protected amino acids (Fmoc-Ala-OH, Fmoc$\mathrm{Asp}(\mathrm{O} t \mathrm{Bu})-\mathrm{OH}$, Fmoc-Asn-(Trt)-OH (TrT: trityl), Fmoc-Gly-OH, Fmoc-His(Trt)-OH, FmocLys(Boc)-OH (Boc: tert-butyloxycarbonyl), Fmoc-Met-OH, Fmoc-Pro-OH, Fmoc-Ser( $t \mathrm{Bu})-$ $\mathrm{OH}$ és Fmoc-Thr( $t \mathrm{Bu})-\mathrm{OH}), \quad$ 2-(1-H-benzotriazole-1-yl)-1,1,3,3-tetramethyluronium tetrafluoroborate (TBTU) and Rink Amide AM resin was purchased from Novabiochem (Switzerland). N,N-diisopropyl-ethylamine (DIEA) and trifluoroacetic acid (TFA) were obtained from Merck Ltd. N-hydroxybenzotriazole (HOBt), N-methyl-pyrrolidone (NMP), triisopropylsilane (TIS), 2,2'-(ethylenedioxy)diethanethiol (DODT), and 2-methyl-2-butanol were Sigma-Aldrich products. Piperidine, dichloromethane (DCM), diethyl ether $\left(\mathrm{Et}_{2} \mathrm{O}\right)$, acetic acid (96\%) and $\mathrm{H}_{2} \mathrm{O}_{2}$ were obtained from Molar Chemicals Ltd whereas peptide synthesis grade N,N-dimethylformamide (DMF), acetonitrile (ACN) and acetic anhydride were from VWR International Ltd. Ethylene diamine tetraacetic acid disodium salt $\left(\mathrm{Na}_{2} \mathrm{EDTA}\right)$ were from Reanal Ltd.

The peptides Ac-SKPKTNMKHM-NH2 (dMKHM), Ac-SKPKTNAKHA-NH $\mathrm{NH}_{2}$ (dAKHA), Ac-SKPKTNMKHA-NH ${ }_{2}$ (dMKHA), Ac-SKPKTNAKHM-NH $\mathrm{N}_{2}$ (dAKHM) and AcMKPKTNAKHA-NH $\mathrm{N}_{2}$ (dM1AKHA) were synthesized by means of a Liberty 1 solid phase peptide synthesizer.

Concentrations of the peptide stock solutions were determined by potentiometric titrations that also supported the purity and the identity of the substances.

Stock solutions of copper(II) chlorides were prepared from analytical grade reagents and their concentration were measured gravimetrically via the precipitation of oxinates. The other stock solutions $(\mathrm{KOH}, \mathrm{HCl}, \mathrm{KCl}$, potassium hydrogen phthalate) were also prepared from analytical grade reagents.

\subsection{Peptide synthesis and purification}

The protected peptides (Scheme 2) were synthesized by means of a microwave-assisted Liberty 1 Peptide Synthesizer (CEM, Matthews, NC) using the Fmoc/tBu technique and the 
TBTU/HOBt/DIPEA (DIPEA: N,N-Diisopropylethylamine) activation strategy. Removal of the Fmoc protecting group was carried out at $80^{\circ} \mathrm{C}$ with 30 Watts microwave power for $180 \mathrm{~s}$ by means of $20 \%$ piperidine in DMF. Four times excess of amino acids and $30 \mathrm{~W}$ microwave power for $300 \mathrm{~s}$ were used for coupling at $80{ }^{\circ} \mathrm{C}$ in the presence of $0.5 \mathrm{M} \mathrm{HOBt}$ and $0.5 \mathrm{M}$ TBTU in DMF as an activator and $2 \mathrm{M}$ DIPEA as an activator base. In the case of the peptides the free amino terminus was treated with DMF containing $5 \mathrm{~V} / \mathrm{V} \% \mathrm{Ac}_{2} \mathrm{O}$ and 6 V/V\% DIPEA to obtain the acetylated amino group. The prepared peptide linked to the resin was washed with dichloromethane, 96\% acetic acid, 2-methyl-2-butanol and diethyl ether. The side chain protecting groups were cleaved with the mixture of TFA/TIS/ $\mathrm{H}_{2} \mathrm{O} / \mathrm{DODT}$ $(94 / 2.5 / 2.5 / 1 \mathrm{~V} / \mathrm{V} \%)$ at room temperature for 2 hours. The solution containing the peptide was separated from the resin by filtration, followed by recovering from the pertinent solution by precipitation with cold diethyl ether. The precipitate was washed with cold diethyl ether, then was centrifuged and dried, redissolved in water and finally lyophilized.

The purity of the peptides was checked by analytical RP-HPLC using a Jasco instrument, equipped with a Jasco MD-2010 plus multiwavelength detector. The chromatographic conditions are as follows: Column: Teknokroma Europa Protein C18 $(250$ x 4.6 mm, $300 \AA$ pore size, $5 \mu \mathrm{m}$ particle size); elution: gradient elution was carried out using solvent A $(0.1 \%$ TFA in water) and solvent $\mathrm{B}(0.1 \% \mathrm{TFA}$ in acetonitrile $)$ at a flow rate of $1 \mathrm{~mL} \cdot \mathrm{min}^{-1}$, monitoring the absorbance at $222 \mathrm{~nm}$. From $3 \mathrm{~min}$ to $9 \mathrm{~min} 100 \%$ to $95 \%$ (dAKHA), 92\% (dMKHA, dAKHM, dM1AKHA), 88\% (dMKHM) A, from 9 min to $24 \min 95 \%$ (dAKHA), 92\% (dMKHA, dAKHM, dM1AKHA), 88\% (dMKHM) A and from 24 min to 30 min 95\% (dAKHA), 92\% (dMKHA, dAKHM, dM1AKHA), 88\% (dMHKM) to 100\% A was applied.

\subsection{Potentiometric measurements}

The $\mathrm{pH}$-potentiometric titrations were made in $4.00 \mathrm{~mL}$ samples at $3 \cdot 10^{-3} \mathrm{M}$ ligand concentration with the metal ion to ligand ratio $1: 1$.

The titrations were performed with carbonate free stock solution of potassium hydroxide of known concentration. A MOLSPIN pH-meter equipped with a 6.0234.100 combined glass electrode (Metrohm) was used for $\mathrm{pH}$ measurements (in the $\mathrm{pH}$ range 2.5-11.5), while the dosing of the titrant were made with a MOL-ACS microburette controlled by a computer.

During the measurements argon was bubbled through the samples to ensure the absence of oxygen and carbon dioxide. All pH-potentiometric measurements were carried out at a constant ionic strength of $0.2 \mathrm{M} \mathrm{KCl}$ and at a constant temperature $(298 \mathrm{~K})$. 
The recorded $\mathrm{pH}$ readings were converted to hydrogen ion concentration as described by Irving et al [25]. Protonation constants of the ligands and overall stability $\left(\log \beta_{p q r}\right)$ constants of the metal complexes were calculated by means of the general computational programs (SUPERQUAD [26] and PSEQUAD [27]) based on eqn (1) and (2).

$$
\begin{aligned}
& p \mathrm{M}+q \mathrm{H}+r \mathrm{~L}=\mathrm{M}_{p} \mathrm{H}_{q} \mathrm{~L}_{r} \\
& \beta_{p q r}=\frac{\left\lfloor\mathrm{M}_{p} \mathrm{H}_{q} \mathrm{~L}_{r}\right\rfloor}{[\mathrm{M}]^{p} \cdot[\mathrm{H}]^{q} \cdot[\mathrm{L}]^{r}}
\end{aligned}
$$

\subsection{Spectroscopic measurements}

UV-Vis spectra of the complexes were recorded on Hewlett Packard HP 8453 diode array and Perkin Elmer Lambda 25 double beam spectrophotometers. The same concentration range was used as for $\mathrm{pH}$-potentiometry.

Circular dichroism spectra of the complexes were registered on a JASCO J-810 spectropolarimeter using $1 \mathrm{~mm}$ and/or cm cells in the $200-800 \mathrm{~nm}$ wavelength range at the same concentrations as used in $\mathrm{pH}$-potentiometry.

\subsection{Oxidation of Human Prion fragment and its mutants}

The reaction mixture containing $1.1 \mathrm{mM}$ of peptides and metal-to-ligand molar ratio 1:1.1 was incubated at $25{ }^{\circ} \mathrm{C}$ for $1 \mathrm{~h}$ in the presence of hydrogen peroxide at metal to $\mathrm{H}_{2} \mathrm{O}_{2}$ molar ratio 1:4 for all peptides. The $\mathrm{pH}$ was adjusted to 7.4. The reaction was started by the addition of hydrogen peroxide, which was freshly prepared. After incubation the reaction was stopped by addition of $\mathrm{Na}_{2}$ EDTA at ligand to $\mathrm{Na}_{2}$ EDTA ratio 1:5. The reaction process was monitored by RP-HPLC at different time periods. The chromatograms of the reaction mixtures after 1 hour 2, 4 and 24 and 96 hour indicated no significant difference (the shape, retention times and intensity of peaks) suggesting the end of reaction after 1 hour.

\subsection{Isolation of oxidized products}

The samples were analyzed by analytical RP-HPLC using a Jasco instrument, equipped with a Jasco MD-2010 plus multiwavelength detector. The oxidized products were conducted on a Teknokroma Europa Protein C18 $(250 \times 4.6 \mathrm{~mm}, 300 \AA \AA, 5 \mu \mathrm{m})$ at a flow rate of $1 \mathrm{~mL} \cdot \mathrm{min}^{-1}$, monitoring the absorbance at $222 \mathrm{~nm}$. Mobile phases were water (A) and acetonitrile (B) containing 0.1\% TFA. Gradient: 0-3-9-24-30 min, 100-100-95-95-100\% water containing 
0.1\% TFA for dAKHA; 0-3-9-24-30 min, 100-100-92-92-100\% water containing $0.1 \%$ TFA for dAKHM, dMKHA, dM1AKHA; 0-3-9-24-30 min, 100-100-88-88-100\% water containing $0.1 \%$ TFA for dMKHM.

The oxidized mixture was separated by RP-HPLC semipreparative 218 TP C18 Grace Vydac column $(250 \times 10 \mathrm{~mm}, 5 \mu \mathrm{m})$. Reverse phase HPLC was performed on a Jasco instrument, equipped with a Jasco UV-2077 Plus 4- $\lambda$ Intelligent UV/Vis detector. The flow rate of 3 $\mathrm{mL} \cdot \mathrm{min}^{-1}$ was maintained. The elution of peptides was monitored by UV absorbance at 222 $\mathrm{nm}$. Above mentioned gradient elution was used at this system.

\subsection{Mass spectrometry}

A MicroTOF-Q type Qq-TOF MS instrument (Bruker Daltonik, Bremen, Germany) was used for the MS and MS/MS measurements in positive ion mode. The instrument was equipped with an electrospray ion source where the spray voltage was $4 \mathrm{kV} . \mathrm{N}_{2}$ was utilized as drying gas. The drying temperature was $200{ }^{\circ} \mathrm{C}$ and the flow rate was $4.0 \mathrm{~L} / \mathrm{min}(8.0 \mathrm{~L} / \mathrm{min}$ HPLCMS) using the same method described in 2.6. For the MS/MS experiments, nitrogen was used as the collision gas. The pressure in the collision cell was determined to be $1.2 \times 10^{-2}$ mbar. The precursor ions for MS/MS were selected with an isolation width of $5 \mathrm{~m} / \mathrm{z}$ units. The mass spectra were recorded by means of a digitizer at a sampling rate of $2 \mathrm{GHz}$. The mass spectra were calibrated externally using the exact masses of clusters $\left[(\mathrm{NaTFA})_{\mathrm{n}}+\mathrm{Na}\right]^{+}$generated from the electrosprayed solution of sodium trifluoroacetate (NaTFA). The spectra were evaluated with the DataAnalysis 3.4 software from Bruker. The sample solutions were introduced either directly into the ESI source with a syringe pump (Cole-Parmer Ins. Co., Vernon Hills, IL, USA) at a flow rate of $3 \mu \mathrm{L} / \mathrm{min}$.

\section{Results and discussion}

\subsection{Protonation equilibria of the peptides}

The protonation constants of the ligands were determined by $\mathrm{pH}$-potentiometric measurements and the $\mathrm{pK}$ values are included in Table 1 together with the stability constants of the copper(II) complexes. It is clear from Table 1 that all decapeptides have four protonation sites which can be assigned to the imidazole nitrogen atom of His111 and $\varepsilon$ amino groups of Lys104, Lys106 and Lys110. The protonation reactions of the imidazole 
nitrogen atoms of histidyl and the $\varepsilon$-amino groups of lysyl residues are well separated and take place in the $\mathrm{pH}$ ranges 5.5-7.0 and 9.5-11.5, respectively. These values are in good agreement with other fragments of prion proteins [28].

\subsection{Copper(II) complexes of the peptides}

Since the studied ligands contain only one anchor group, namely histidine imidazole nitrogen, and according to the previous observations [28], it was suggested that only 1:1 complexes are formed. Therefore the copper(II)-peptide systems were investigated only at 1:1 metal ion-to ligand ratio. The metal ion speciations of the five systems are very similar to each other, this is represented by Figure 1. It is clear from Table 1 and Figure 1 that, in all systems, complex formation starts around $\mathrm{pH} 4$, forming $\left[\mathrm{CuH}_{3} \mathrm{~L}\right]^{5+}$ species, in which monodentate binding of the histidyl residue is expected, while all the lysyl residues remain protonated. The lack of circular dichroism (CD) activity below $\mathrm{pH} 5.5$ and the calculated $\mathrm{pK}$ value for the formation of this complex provide further support for this assumption. The deprotonation of the amide nitrogens occurs above $\mathrm{pH} 5$, in a cooperative manner, forming the $[\mathrm{CuHL}]^{3+}=\left[\left(\mathrm{CuH}_{-}\right.\right.$ $\left.\left.{ }_{2} \mathrm{~L}\right) \mathrm{H}_{3}\right]^{3+}$ species. This process is accompanied with a significant blue shift of the absorption spectra and the appearance of the $\mathrm{N}^{-} \rightarrow \mathrm{Cu}^{2+} \mathrm{CT}$ bands $\left(\lambda_{\max }=330-350 \mathrm{~nm}\right)$ in the CD spectra (Figure 2). The three uncoordinated lysyl side chains remain protonated in the $\left(\mathrm{N}_{\mathrm{im}}, \mathrm{N}^{-}, \mathrm{N}^{-}\right)$bonded species. In addition to a weak interaction of thioether sulfur atoms of methionine can be supposed in the copper(II)-peptide systems, in which Met109 is present. It is supported by the CD spectra, where a positive Cotton effect observed around $380 \mathrm{~nm}$. It can be attributed to the $\mathrm{S}$ (thioether) $\rightarrow \mathrm{Cu}^{2+} \mathrm{CT}$ transitions supporting the equatorial coordination of the thioether residues. However this interaction is much lower than it is in the case of smaller prion fragments [28], which can be explained by the size of the peptides; the long peptide chain hinders the binding of donor atoms due to its flexibility.

The deprotonation of the third amide nitrogen takes place above $\mathrm{pH} 7$ resulting the $[\mathrm{CuL}]^{2+}$ species. There is an absorption maximum around $530 \mathrm{~nm}$ which refers to $4 \mathrm{~N}$ coordination. The S(thioether) $\rightarrow \mathrm{Cu}^{2+} \mathrm{CT}$ disappears at the same time (Figure 2). The thioether sulfur atom is displaced by the third amide nitrogen resulting in a stronger interaction. However, the formation of $\left[\mathrm{CuH}_{-1} \mathrm{~L}\right]^{+},\left[\mathrm{CuH}_{-2} \mathrm{~L}\right]$ and $\left[\mathrm{CuH}_{-3} \mathrm{~L}\right]^{-}$species are not accompanied by any change neither in the absorption nor in the CD spectra. The deprotonation of the lysine ammonium groups occurs in these cases. If the $\mathrm{pK}$ values of these processes are compared with the $\mathrm{pK}$ 
values of the lysine in the free ligand, it can be stated that the lysine side chains do not take part in the coordination of the copper(II) ion.

If the copper(II) complexes of the studied ligands are compared it is obvious that there is no significant difference in the complex formation reactions, neither in their stabilities, nor in their spectroscopic parameters.

\subsection{Oxidation of the peptides}

\subsubsection{Oxidation of dAKHA}

This mutant contains only His111 as the only target of metal-catalyzed oxidation, no methionine residue is present. The oxidation of the peptide was carried out at $\mathrm{pH}$ 7.4. At this $\mathrm{pH}$ there are $\left(\mathrm{N}_{\mathrm{Im}}, \mathrm{N}^{-}, \mathrm{N}^{-}\right)$-bonded $[\mathrm{CuHL}]^{3+}$ species in equilibrium with the $\left(\mathrm{N}_{\mathrm{Im}}, \mathrm{N}^{-}, \mathrm{N}^{-}, \mathrm{N}^{-}\right)$bonded $[\mathrm{CuL}]^{2+}$ species.

The HPLC chromatograms indicate that there is no change in comparison to the peptide, if the solution contains only $\mathrm{Cu}(\mathrm{II})$ and the peptide, or $\mathrm{H}_{2} \mathrm{O}_{2}$ and the peptide. Both $\mathrm{Cu}(\mathrm{II})$ and $\mathrm{H}_{2} \mathrm{O}_{2}$ is needed for the oxidation of dAKHA.

The oxidation of this peptide resulted several products, which is presented on Figure 3. The intensity of these peaks are very low, therefore the identification with LC/MS is not possible. Hence the products were separated by semi-preparative column, and the individual products were studied in MS and MS/MS. The formation of 2-oxo-histidine derivative was not detected in the MS spectra, the fragmentation of the peptide chain occurred. There are two possible mechanism for this process; the $\alpha$-amidation and the diamide pathways [29]. However, only the product ions from the fragmentation of the ligand by the $\alpha$-amidation pathway could be observed with significant intensities. The C-terminal amino acid of the fragment derived from the N-terminal region of the protein exists as the amide derivative and the N-terminal amino acid of the fragment derived from the C-terminal portion of the protein exists as an $\alpha$-ketoacyl derivative. The most abundant product ions are $\mathrm{c}_{4}{ }^{+}$, observed at $\mathrm{m} / \mathrm{z} 500.316$ (calculated value 500.319), $\mathrm{c}_{6}{ }^{2+}$ at $\mathrm{m} / \mathrm{z} 358.212$ (calculated value 358.208 ) and $\mathrm{c}_{7}{ }^{2+}$ at $\mathrm{m} / \mathrm{z} 393.722$ (calculated value 393.727). The cleavage of Lys4-Thr5, Asn6-Ala7 and Ala7-Lys8 peptide bonds can be detected. Furthermore the ion $\mathrm{y}_{3}{ }^{+}$is also detected, which is formed on another pathway. The charge of all the identified ions arises from the presence of protons.

The presence of $c_{7}$ ion as a product of oxidation is proved by the MS/MS spectra on Figure 4 . $\mathrm{c}_{7}$ ion has 2 positive charge with $\mathrm{m} / \mathrm{z} 393.722$ (calculated value 393.727 ). The first step is the loss of ammonia, resulting doubly charged $b_{7}$ ion at $\mathrm{m} / \mathrm{z} 385.289$. Then the loss of alanine can 
be seen, forming doubly charged $b_{6}$ ion at $\mathrm{m} / \mathrm{z} 349.686$. Singly charged $b_{6}$ ion is also formed at $\mathrm{m} / \mathrm{z}$ 698.384. The loss of Asn6 and Thr5 resulting the $\mathrm{b}_{5}{ }^{+}$and $\mathrm{b}_{4}{ }^{+}$ions, is also very well tracked.

\subsubsection{Oxidation of mutant peptides containing one methionine residue (dMKHA and dAKHM)}

Only one product was formed during the oxidation of these peptides. The mass difference between the untreated and the oxidized mutant peptides based on the MS measurements corresponds to the mass of the oxygen atom (15.995) indicating the successful oxidation of these peptides by the addition of one oxygen. Then MS/MS measurements were performed to identify the place of the oxidation in the peptides. It is proved that the oxidation of the methionine to methionine sulfoxide occurred in both cases, but the results will be shown in details only for the peptide dAKHM. Chromatographic peak eluting at $20.6 \mathrm{~min}$ and in the MS spectra occurring at $\mathrm{m} / \mathrm{z} 599.826$ (calculated value 599.822) correspond to the doubly charged molecular ion of dAKHM after oxidation $\left(\left[\mathrm{y}_{10}+\mathrm{O}\right]^{2+}\right)$. The fragmentation of this ion is presented on Figure 5. It begins on the N-terminus, and the amino acids are removed step by step. All the fragments contain the oxygen atoms, since the methionine residue (Met109) is on the C-teminus. The final fragment is $\left[\mathrm{y}_{1}+\mathrm{O}\right]^{+}$with $165.070 \mathrm{~m} / \mathrm{z}$ (calculated 165.069), which is the oxidized form of methionine. A peak corresponding to the loss of $\mathrm{CH}_{3} \mathrm{SOH}$ (63.998) are observed at $\mathrm{m} / \mathrm{z} 567.826$ (calculated value 567.823) with $\left[\mathrm{y}_{10}+\mathrm{O}-\mathrm{CH}_{3} \mathrm{SOH}\right]^{2+}$ stoichiometry. It is also diagnostic for the formation and presence of methionine sulfoxide $[30]$.

The molecular weight of dMKHA and the mass of its oxidized product are equal to these values of dAKHM, the only difference is in the position of the methionine residue. The oxidation of the methionine residue (Met112) at position 7 is proved, it is confirmed by the above mentioned loss of $\mathrm{CH}_{3} \mathrm{SOH}$. However, fragments supporting the oxidation of histidine were not identified. e.g. $\left[\mathrm{y}_{2}\right]^{+}$fragment with $226.135 \mathrm{~m} / \mathrm{z}$ (calculated value 226.130 ) contains only histidine and alanine, $\left[\mathrm{y}_{2}+\mathrm{O}\right]^{+}$did not revealed.

\subsubsection{Oxidation of dMKHM}

Several products were formed during the oxidation of this prion protein fragment (Figure 6). The products were separated by semi-preparative column, and the individual products were studied in MS. Two main products can be identified. This peptide was not fragmentized, only the addition of one or two oxygen atoms can be seen. The species eluted at $12.0 \mathrm{~min}$ is a 
doubly oxidized, the species eluted at $13.2 \mathrm{~min}$ is a singly oxidized product. According the MS/MS measurements it is proved that only the methionine residue is oxidized, the histidine residue did not change during the oxidation.

The species with $637.818 \mathrm{~m} / \mathrm{z}$ (calculated 637.821) has two positive charges due to the presence of the hydrogen atoms. The mass of this ion is 31.990 units higher than that of the nonoxidized peptide. This species is named as $\left[\mathrm{y}_{10}+2 \mathrm{O}\right]^{2+}$, corresponding to the addition of two oxygen atoms to the fragment. The fragmentation of this species begins at the N-terminal part of the peptide; it is shown on Figure 7. Fragments containing only even-numbered amino acids, namely $\mathrm{y}_{8}+2 \mathrm{O}, \mathrm{y}_{6}+2 \mathrm{O}$ and $\mathrm{y}_{4}+2 \mathrm{O}$, could be identified. The loss of amino acids occurred in pairs. The latter fragment still contains two oxygen atoms, its sequence is MetLysHisMet+2O. The additional oxygen atoms could stay either on the histidine or on the methionine residues. Histidine is also dispose for oxidation, but it was not detected in our case. There are several proofs for the oxidation of the methionine residues; for example a peak with m/z: 165.069 (calculated 165.069) for [MetO] ${ }^{+}$. However, the oxidized histidine (His $+\mathrm{O}$ ) or any loss referring the to the oxidation of this amino acid residue was not observed at all in the MS/MS spectra. It is obvious from the MS/MS spectra that only methionine sulfoxides are produced, neither methionine sulfone nor histidine-oxide is formed.

The singly oxidized products are observed at $629.820 \mathrm{~m} / \mathrm{z}$ (calculated 629.824), namely $\left[\mathrm{y}_{10}+\mathrm{O}\right]^{2+}$. Both methionine residues at position 7 (Met109) and at position 10 (Met112) can be oxidized respectively. None of these residues is preferred over the other one; their oxidation occurs randomly. However, the two products are not separated in the HPLC chromatogram.

Oxidation of the Met109 residue can be proved by the $\left[\mathrm{b}_{9}+\mathrm{O}\right]^{2+}$ with $555.788 \mathrm{~m} / \mathrm{z}$ (calculated 555.790 ) and the $\left[\mathrm{y}_{2}\right]^{+}$with $286.130 \mathrm{~m} / \mathrm{z}$ (calculated 286.134) peaks. $\left[\mathrm{b}_{9}+\mathrm{O}\right]^{2+}$ contains the oxygen atom on Met109 since the C-terminal Met112 is removed. If eight amino acids are fragmented from the N-terminal part of the oxidized product yields $\left[\mathrm{y}_{2}\right]^{+}$fragment, in which Met112 is present, the oxygen atom is removed with Met109.

Oxidation of the Met112 residue can be proved by $\left[\mathrm{y}_{2}+\mathrm{O}\right]^{+}$with $302.127 \mathrm{~m} / \mathrm{z}$ (calculated 302.129) and $\left[\mathrm{y}_{1}+\mathrm{O}\right]^{+}$with $165.069 \mathrm{~m} / \mathrm{z}$ (calculated 165.069) peaks. $\left[\mathrm{y}_{2}+\mathrm{O}\right]^{+}$contains only one methionine, therefore oxygen atom is on this Met112. In the latter fragment the oxygen could be on the histidine residue, however the $\left[\mathrm{y}_{1}+\mathrm{O}\right]^{+}$fragment still contains the oxygen atoms, therefore the oxidation of Met1 12 is proved. 
In the case of the studied peptides which contain methionine in close vicinity of the metalbinding site, the oxidation of this group occurred. Therefore a newer mutant peptide was synthesized and studied in which the methionine is far from the coordinated metal ion.

\subsubsection{Oxidation of dM1AKHA}

The serine is replaced by methionine residue and the methionine residues are replaced by alanine in this mutant peptide. The condition of oxidation was the same. The oxidation of the peptide occurred. The oxidation of the methionine residue is proved again by MS/MS (Figure 8). $\left[\mathrm{y}_{10}+\mathrm{O}\right]^{2+}$ with $591.821 \mathrm{~m} / \mathrm{z}$ (calculated 591.824) is the main product, the loss of $\mathrm{CH}_{3} \mathrm{SOH}$ group results in $\left[\mathrm{y}_{10}+\mathrm{O}-\mathrm{CH}_{3} \mathrm{SOH}\right]^{2+}$ with $559.823 \mathrm{~m} / \mathrm{z}$ (calculated 559.825) which is consistent with the oxidation of the methionine residue. There are several other proofs for it. $\left[b_{1}+O\right]^{+}$is the oxidized form of acetil-methionine with $190.055 \mathrm{~m} / \mathrm{z}$ (calculated 190.054). The identified y fragments do not contain oxygen with the exception of the methionine containing $\mathrm{y}_{10}$.

\section{Conclusions}

The coordination chemistry of the five studied decapeptides is rather similar to each other including the stability and the coordination mode of the copper(II) complexes. The only difference is, that in the peptides which contain Met109, in addition to the $\left(\mathrm{N}_{\mathrm{im}}, \mathrm{N}^{-}, \mathrm{N}^{-}\right)$ coordination mode, a weak interaction of thioether sulfur atoms can be supposed.

The histidine residue behaves as an anchor site, and the $\left(\mathrm{N}_{\mathrm{im}}, \mathrm{N}^{-}, \mathrm{N}^{-} / \mathrm{N}_{\mathrm{im}}, \mathrm{N}^{-}, \mathrm{N}^{-}, \mathrm{N}^{-}\right)$ coordination modes prevent the oxidation of this side chain. The mutant peptide which does not contain methionine did not undergo oxidation, only the fragmentation of the peptide chain is perceived. The cleavage of the peptide bonds occurred far away from the histidine residue. However, in the case of methionine containing peptides, the peptide chain was not cleaved; the presence of methionine residues protects the peptides from fragmentation. In these cases copper(II) ions catalyze the oxidation of methionine to methionine sulfoxide. This process occurs randomly, it does not depend on the position of the methionine; methionine residues undergo oxidation either involved in the coordination of the copper(II) ions, or near or far the binding sites. Methionine oxidation is considered to be a destabilizing trigger that causes the cascade of events leading to PrP misfolding [31,32]. However, the sizes of the studied decapeptides are too short for reaching so extensive conclusions. Our results revealed that methionine residues of prion protein can play a role as ROS scavenger. The oxidation of 
methionine residues in these short peptides containing only one histidine is able to protect the peptides from oxidation and degradation. To decide whether this effect of methionine prevails in the prion protein as well and to understand that these oxidation processes how affect the misfolding of proteins the longer fragments containing two or more histidines will be studied in continuation of our work.

\section{Abbreviation:}

\begin{tabular}{|l|l|}
\hline ACN & acetonitrile \\
\hline CD & circular dichroism spectroscopy \\
\hline dAKHA & Ac-SKPKTNAKHA-NH ${ }_{2}$ \\
\hline dAKHM & Ac-SKPKTNAKHM-NH 2 \\
\hline DCM & dichloromethane \\
\hline DIEA & N,N-diisopropyl-ethylamine \\
\hline DIPEA & N,N-Diisopropylethylamine \\
\hline DMF & N,N-Dimethylmethanamide \\
\hline dM1AKHA & Ac-MKPKTNAKHA- $\mathrm{NH}_{2}$ \\
\hline dMKHA & Ac-SKPKTNMKHA-NH 2 \\
\hline dMKHM & Ac-SKPKTNMKHM-NH 2 \\
\hline DODT & 2,2'-(Ethylenedioxy)diethanethiol \\
\hline Fmoc & Fluorenylmethyloxycarbonyl \\
\hline HOBt & 1H-Benzotriazol-1-ol \\
\hline Hu-PrP & cellular human prion protein \\
\hline MCO & metal ion-catalyzed oxidation \\
\hline MS & mass spectrometry \\
\hline NMP & N-methyl-pyrrolidone \\
\hline ROS & reactive oxygen species \\
\hline RP-HPLC & $\begin{array}{l}\text { Reversed-Phase } \\
\text { Chromatography }\end{array}$ \\
\hline TFA & trifluoroacetic acid \\
\hline TBTU & $\begin{array}{l}\text { 2-(1H-Benzotriazole-1-yl)-1,1,3,3- } \\
\text { tetramethyluronium tetrafluoroborate }\end{array}$ \\
\hline tBu & tert-Butyl \\
\hline TFA & trifluoroacetic acid \\
\hline TIS & triisopropylsilane \\
\hline TrT & trityl \\
\hline TSEs & transmissible spongiform encephalopathies \\
\hline UV-Vis & UV-visible spectroscopy \\
\hline
\end{tabular}

\section{Acknowledgements}

The authors thank the Hungarian Scientific Research Fund (NK 105156, K 115480 and K $116465)$ for the financial support. This research was also supported by the EU and cofinanced by the European Regional Development Fund under the project GINOP-2.3.2-152016-00008. Furthermore this research was supported by János Bolyai Scholarship. 


\section{References}

[1] D.C. Bolton, M.P. McKinley, S.B. Prusiner, Science 218 (1982) 1309 -1311.

[2] R. Riek, S. Hornemann, G. Wider, M. Billeter, R. Glockshuber, K. Wüthrich, Nature (London) 382 (1996) 180-182.

[3] K.-M. Pan, M. Baldwin, J. Nguyen, M. Gasset, A. Serban, D.Groth, I. Mehlhorn, Z. Huang, R.J. Fletterick, F.E. Cohen, S.B. Prusiner, Proc. Natl. Acad. Sci. USA 90, (1993) 10962-10966.

[4] N. Stahl, D.R. Borchelt, K. Hsiao, S.B. Prusiner, Cell 51 (1987), 229-240.

[5] H. Büeler, M. Fischer, Y. Lang, H. Bluethmann, H.P. Lipp, S.J. Dearmond, S.B. Prusiner, M. Aguet, C. Weissmann, Nature 356 (1992) $577-582$.

[6] J. Collinge, M.A. Whittington, K.C.L. Sidle, C.J. Smith, M.S. Palmer, A.R. Clarke, J.G. R. Jefferys, Nature 370 (1994) 295 - 297.

[7] J.P. Brockes, Curr. Opin. Neurobiol. 9 (1999) 571-577.

[8] D.R. Brown, Trends Neurosci. 24 (2001) 85-90.

[9] G. Di Natale, I. Turi, G. Pappalardo, I. Sóvágó, E. Rizzarelli Chem. Eur. J. 2015, 21, 4071-4084.

[10] G. Arena, D. La Mendola, G. Pappalardo, I. Sóvágó, E. Rizzarelli, Coord. Chem. Rev., 256 (2012) 2202-2218.

[11] S.Y. Choi, H.Y. Kwon, O.B. Kwon, W.S. Eum, J.H. Kang, Biochimie, 82 (2000) 175180 .

[12] C.C. Curtain, F.E. Ali, D.G. Smith, A.I. Bush, C.L. Masters, K.J. Barnham, J. Biol. Chem. 278(5) (2003) 2977-2982.

[13] D.C. Ramirez, S.E.G. Mejiba, R.P. Mason, J. Biol. Chem. 280 (2005) 27402-27411.

[14] C.L. Hawkins, M.J. Davies, Biochim. Biophys. Acta, 1360 (1997) 84-96.

[15] K. Uchida, S. Kawakishi, J. Biol. Chem., 269 (1994) 2405-2410.

[16] A. Krezel, W. Bal, Acta Biochim. Pol. 46 (1999) 567-580.

[17] F. Zhao, E. Ghezzo-Schoneich, G.I. Aced, J. Hong, T. Milby, C. Schoneich, J. Biol. Chem. 272 (1997) 9019-9029.

[18] S.Li, T.H.Nguyen, C. Schoneich, R.T. Borchardt, Biochem. 34 (1995) 5762-5772.

[19] A. Amici, R.L.Levine, L. Tsai, E.R. Stadtman, J. Biol. Chem., 264 (1989) 3341-3346.

[20] Stadtman, E.R., Free Radic. Biol. Med. 9 (1990) 315-325.

[21] C.C. Chao, Y.S. Ma, E.R. Stadtman, Proc. Natl. Acad. Sci. USA, 94 (1997) 2969-2974.

[22] M.L. McKee, J. Am. Chem. Soc. 120 (1998) 3963-3969. 
[23] F. Jensen, A. Greer, and E.L. Clennan, J. Am. Chem. Soc., 120 (1998) 4439-4449.

[24] P. Roepstorff, J. Fohlman, Biomed. Mass Spectrom. 11 (11) (1984) 601.

[25] H. Irving, G. Miles, L.D. Pettit, Anal. Chim. Acta 38 (1967) 475-488.

[26] L. Zékány and I. Nagypál, Computational Methods for the Determination of Stability Constants, ed. D. J. Leggett, Plenum Press, New York, 1985.

[27] P. Gans, A. Sabatini and A. Vacca, J. Chem. Soc., Dalton Trans., 1985, 1195-1200.

[28] G. Di Natale, G. Grasso, G. Impellizzeri, D. La Mendola, G. Micera, N. Mihala, Z. Nagy, K. Ősz, G. Pappalardo, V. Rigó, E. Rizzarelli, D. Sanna, I. Sóvágó, Inorg. Chem., 44 (2005) 7214-7225.

[29] W.M. Garrison, Chem. Rev. 87 (1987) 381-398.

[30] J.D. Bridgewater, R.W. Vachet, Anal. Biochem. 341 (2005) 122 - 130.

[31] M.I. Elmallah, U. Borgmeyer, C. Betzel, L. Redecke, Prion 7 (2013) 404-411.

[32] Z.Wang, B. Fenga, G. Xiao, Z. Zhou, Biochim. Biophys. Acta 1864 (2016) 346-358. 
Table 1: pK values and stability constants of the copper(II) complexes of the studied peptides ( $\mathrm{I}=0.2 \mathrm{M} \mathrm{KCl}, \mathrm{T}=298 \mathrm{~K}$, standard deviations are in parentheses)

\begin{tabular}{|c|c|c|c|c|c|c|}
\hline & \multirow[b]{2}{*}{$\begin{array}{c}\text { Ac-SKPKTN } \\
\text { AKHA-NH }_{2} \\
(\mathrm{dAKHA})\end{array}$} & \multirow[b]{2}{*}{$\begin{array}{c}\text { Ac-SKPKTN } \\
\text { AKHM-NH }_{2} \\
(\mathrm{dAKHM})\end{array}$} & \multirow[b]{2}{*}{$\begin{array}{c}\mathrm{Ac}-\mathrm{SKPKTN} \\
{\mathrm{MKHA}-\mathrm{NH}_{2}} \\
\text { (dMKHA) }\end{array}$} & \multicolumn{2}{|l|}{ Ac-SKPKTN } & \multirow[b]{2}{*}{$\begin{array}{c}\mathrm{Ac}-\mathrm{KTNMK} \\
\mathrm{HMAG}-\mathrm{NH}_{2} \\
\mathrm{HuPrP}(106- \\
114)[28]\end{array}$} \\
\hline & & & & $\begin{array}{c}\mathrm{MKHM}-\mathrm{NH}_{2} \\
\mathrm{HuPrP}(103- \\
112) \\
\text { (dMKHM) }\end{array}$ & $\begin{array}{l}\text { Ac-MKPKTN } \\
\text { AKHA-NH }_{2} \\
(\mathrm{dM} 1 \mathrm{AKHA})\end{array}$ & \\
\hline pK(Im) & $6.28(2)$ & $6.15(1)$ & $6.23(2)$ & $6.15(2)$ & $6.20(5)$ & 6.24 \\
\hline $\mathrm{pK}\left(\mathrm{Lys}_{1}\right)$ & $9.80(2)$ & $9.73(1)$ & $9.77(1)$ & $9.75(2)$ & $9.62(4)$ & 9.91 \\
\hline $\mathrm{pK}\left(\mathrm{Lys}_{2}\right)$ & $10.37(1)$ & $10.36(1)$ & $10.34(1)$ & $10.34(1)$ & 10.39(3) & 10.54 \\
\hline $\mathrm{pK}\left(\mathrm{Lys}_{3}\right)$ & $10.97(2)$ & $10.76(1)$ & $11.05(2)$ & $10.92(2)$ & $10.75(4)$ & - \\
\hline $\mathrm{CuLH}_{3}$ & $34.67(2)$ & $34.53(4)$ & $35.01(2)$ & $34.84(2)$ & $34.73(4)$ & \\
\hline $\mathrm{CuLH}_{2}$ & & & & & & 23.54 \\
\hline $\mathrm{CuLH}$ & $22.56(1)$ & $22.69(2)$ & $23.21(1)$ & $23.28(2)$ & $22.46(2)$ & 17.61 \\
\hline $\mathrm{CuL}$ & $15.03(2)$ & $15.06(3)$ & $15.73(2)$ & $15.82(2)$ & $14.69(3)$ & 12.39 \\
\hline $\mathrm{CuLH}_{-1}$ & $5.29(2)$ & $5.31(3)$ & $5.94(2)$ & $6.08(3)$ & $4.99(4)$ & 4.56 \\
\hline $\mathrm{CuLH}_{-2}$ & $-5.16(2)$ & $-5.36(4)$ & $-4.53(2)$ & $-4.43(3)$ & $-5.56(4)$ & -5.45 \\
\hline $\mathrm{CuLH}_{-3}$ & $-15.99(2)$ & $-15.94(3)$ & $-15.40(2)$ & $-15.14(2)$ & $-16.13(4)$ & -16.11 \\
\hline $\mathrm{pK}_{\text {amide(1-2) }}$ & 6.06 & 5.92 & 5.9 & 5.78 & 6.14 & 5.58 \\
\hline $\mathrm{pK}_{\text {amide(3) }}$ & 7.53 & 7.63 & 7.48 & 7.46 & 7.77 & 7.83 \\
\hline $\lg \mathrm{K}(\mathrm{Cu}+\mathrm{L})$ & 3.53 & 3.68 & 3.85 & 3.83 & 3.97 & 3.09 \\
\hline
\end{tabular}


Scheme1: Peptide fragmentation notation using the scheme of Roepstorff and Fohlman [24]

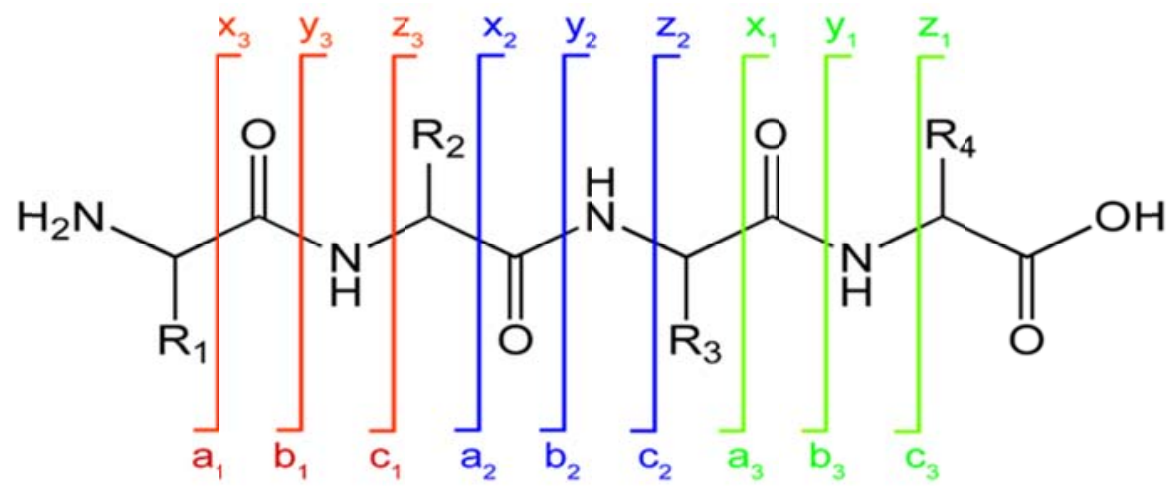


Scheme 2

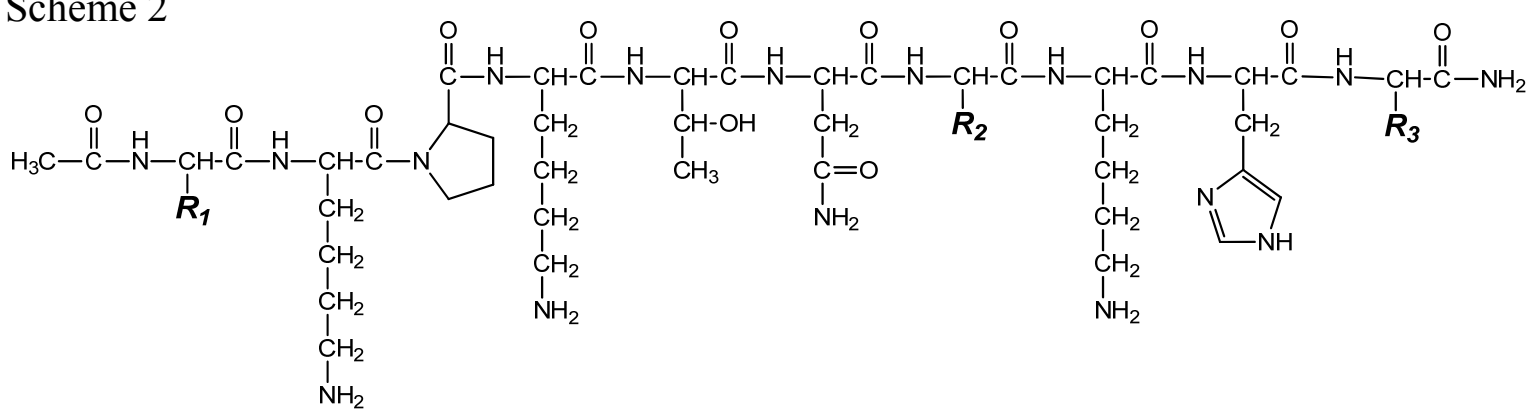

$\mathrm{R}_{1}, \mathrm{R}_{2}, \mathrm{R}_{3}=\mathrm{A} / \mathrm{M} / \mathrm{S}$

$\mathrm{A}=-\mathrm{CH}_{3}$

$\mathrm{M}=-\mathrm{CH}_{2}-\mathrm{CH}_{2}-\mathrm{S}-\mathrm{CH}_{3}$

$\mathrm{S}=-\mathrm{CH}_{2}-\mathrm{OH}$

\begin{tabular}{|l|c|c|c|}
\hline Peptide & $\boldsymbol{R}_{\mathbf{1}}$ & $\boldsymbol{R}_{\mathbf{2}}$ & $\boldsymbol{R}_{\mathbf{3}}$ \\
\hline dAKHA & S & A & A \\
\hline dAKHM & S & A & M \\
\hline dMKHA & S & M & A \\
\hline dMKHM & S & M & M \\
\hline dM1AKHA & M & A & A \\
\hline
\end{tabular}




\section{Figure legends}

Figure 1: Species distribution of the complexes formed in the copper(II)-decapeptides systems $\left(\mathrm{c}_{\mathrm{Cu}(\mathrm{II})}=\mathrm{c}_{\mathrm{L}}=3 \cdot 10^{-3} \mathrm{M}\right)$ as a function of $\mathrm{pH}$.

Figure 2: Circular dichroism spectra of the $\left(\mathrm{N}_{\mathrm{Im}}, \mathrm{N}^{-}, \mathrm{N}^{-}\right)$-bonded $[\mathrm{CuHL}]^{3+}$ and the $\left(\mathrm{N}_{\mathrm{Im}}, \mathrm{N}^{-}, \mathrm{N}^{-}\right.$ , $\mathrm{N}^{-}$)-bonded $[\mathrm{CuL}]^{2+}$ complexes formed in the studied system

Figure 3: HPLC chromatogram of the products forming during the oxidation of dAKHA

Figure 4: Fragmentation of $c_{7}$ ion formed during the oxidation of dAKHA

Figure 5: MS/MS spectrum of the oxidized product of dAKHM

Figure 6: HPLC chromatogram of the products forming during the oxidation of dMKHM

Figure 7: MS/MS spectra of the double oxidized product of dMKHM

Figure 8: MS/MS spectrum of the oxidized product of dM1AKHA 


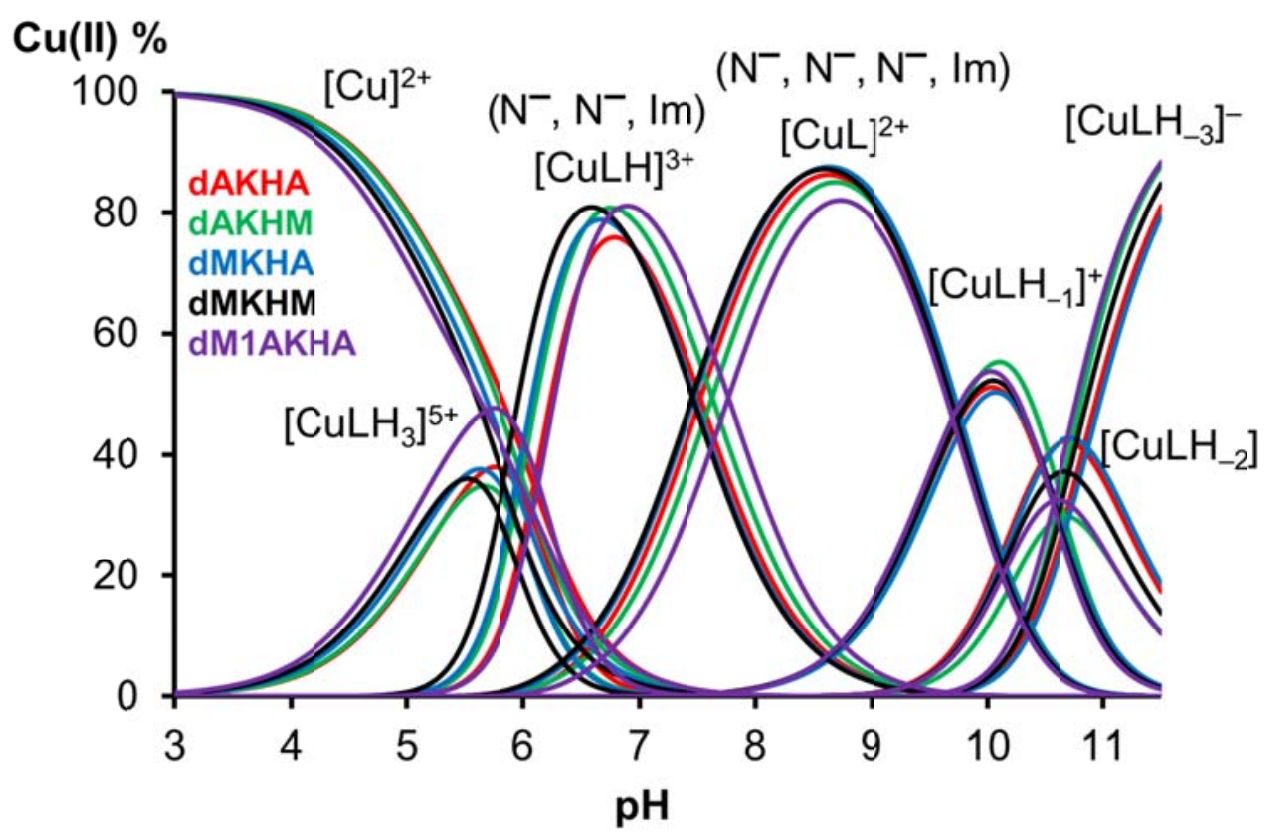

Figure 1 


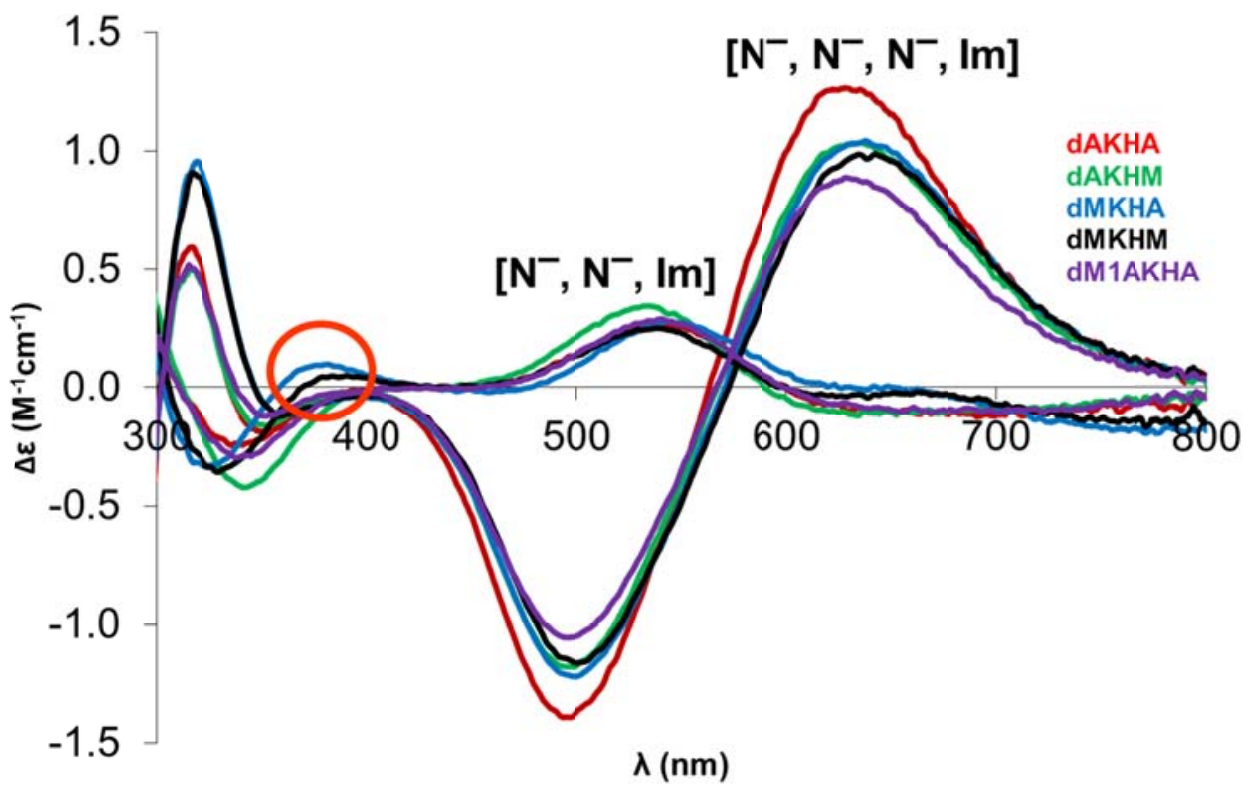

Figure 2 


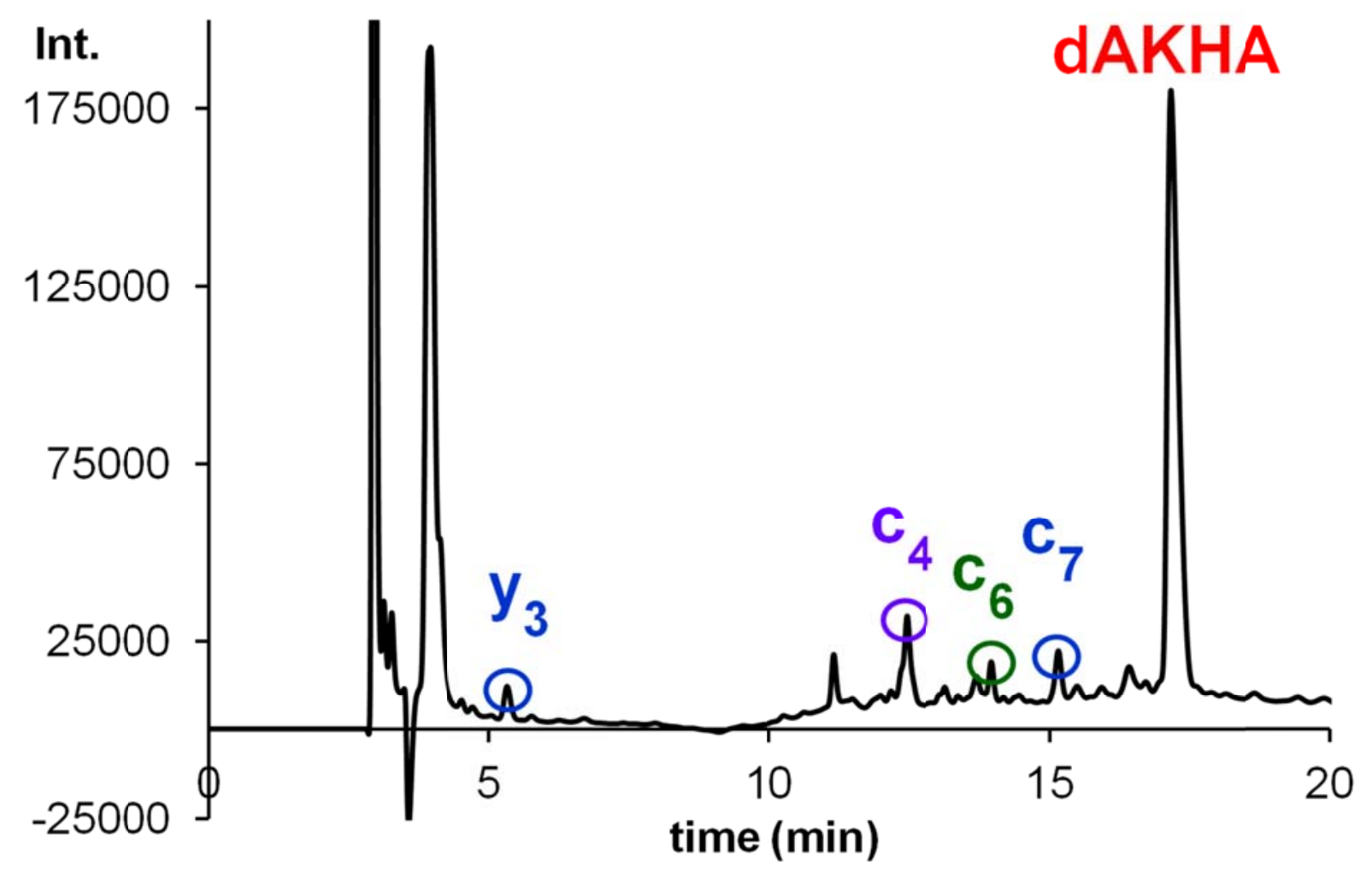

Figure 3 
Intens.

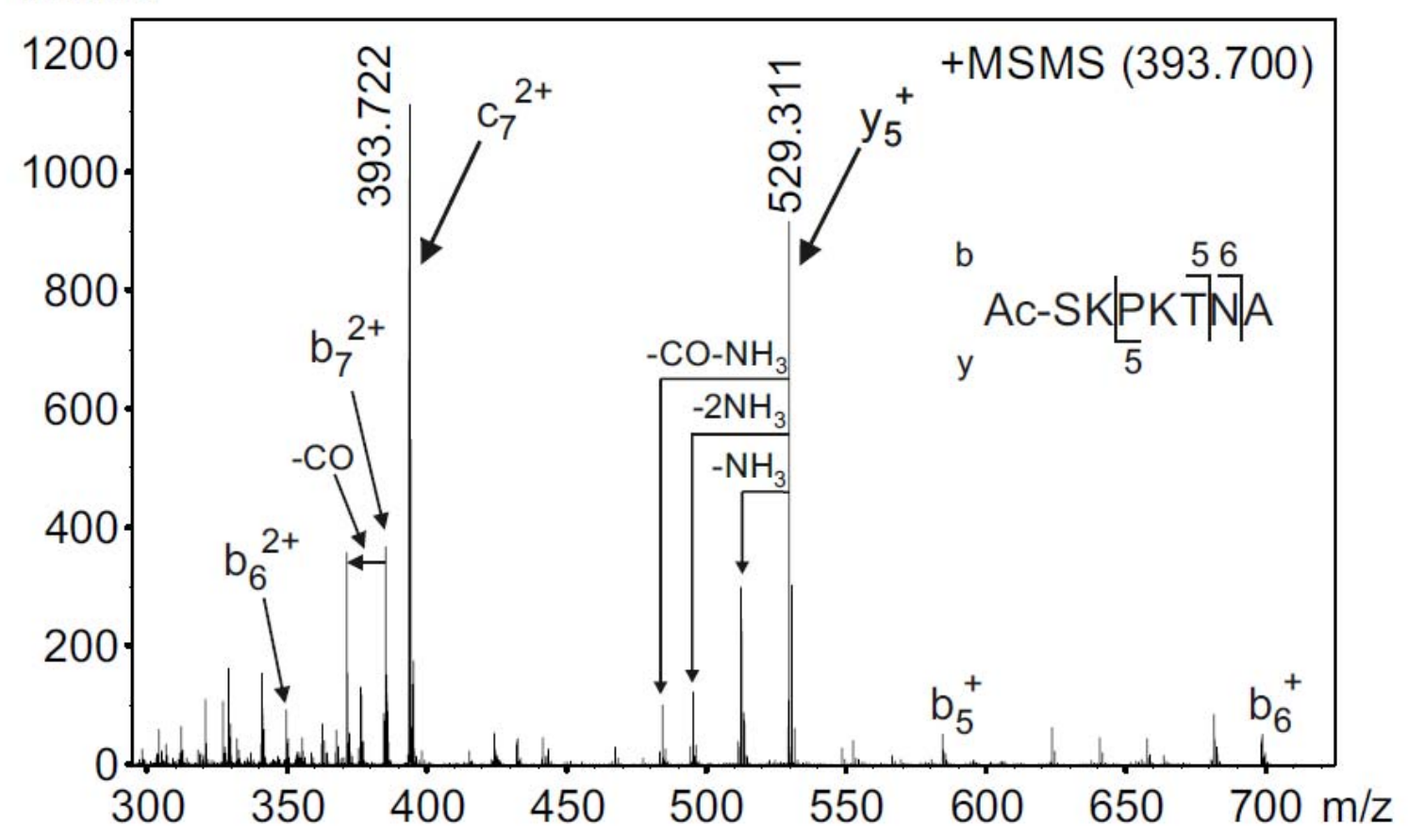

Figure 4 


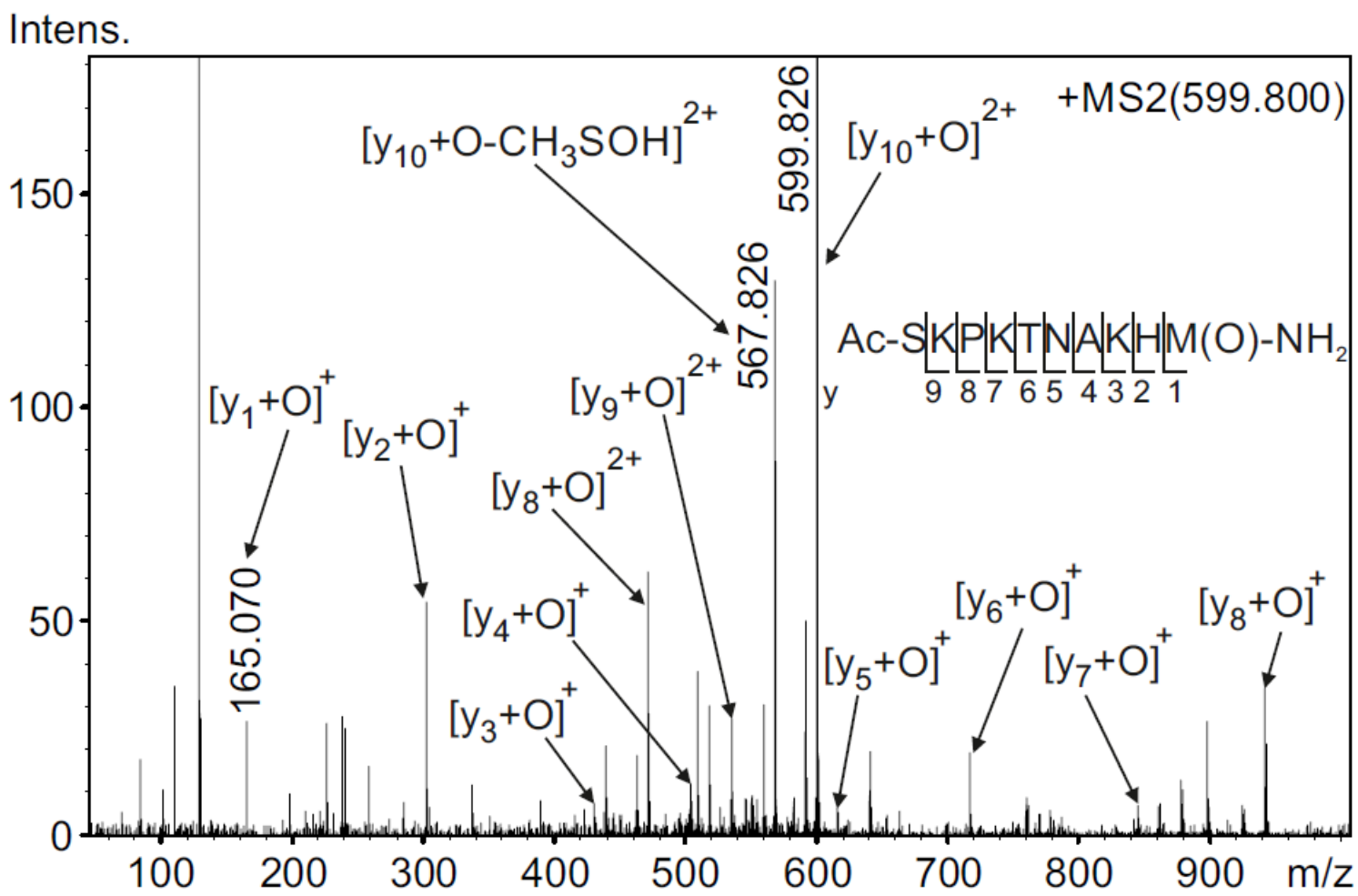

Figure 5 


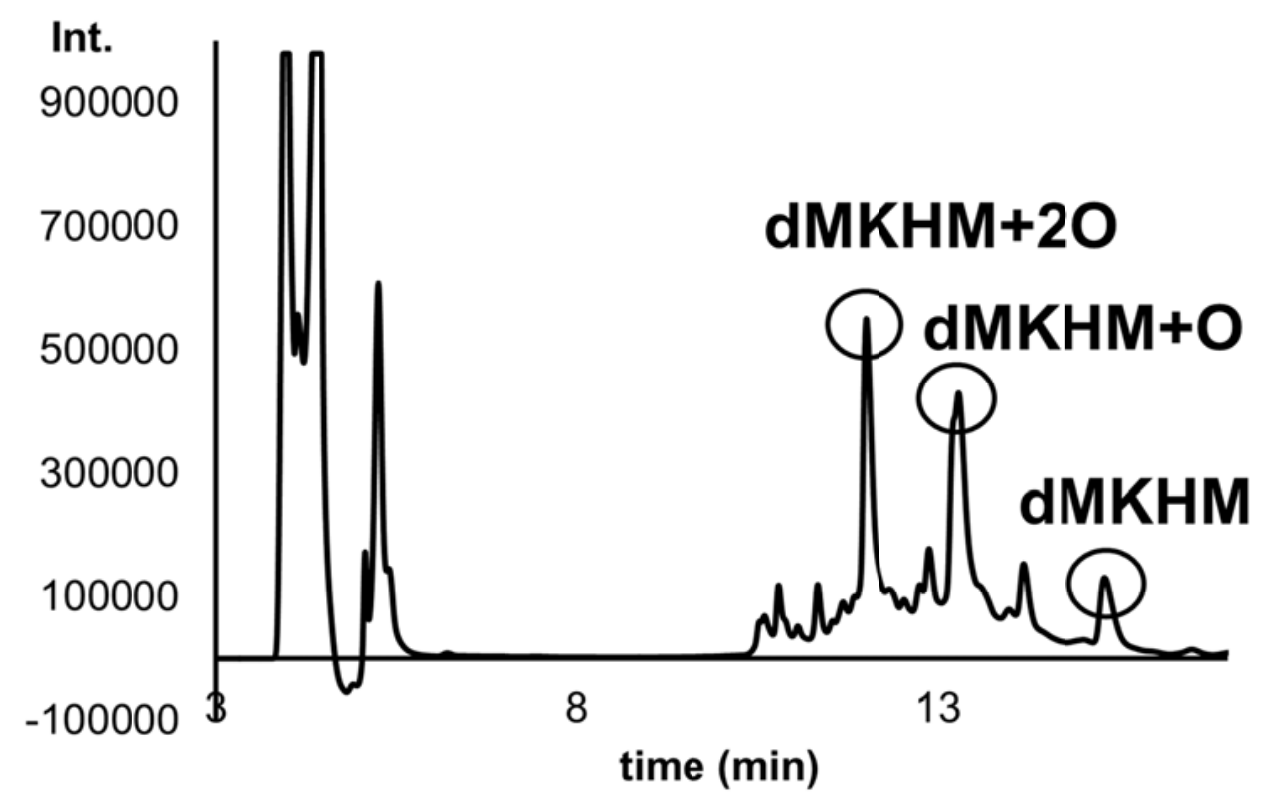

Figure 6 


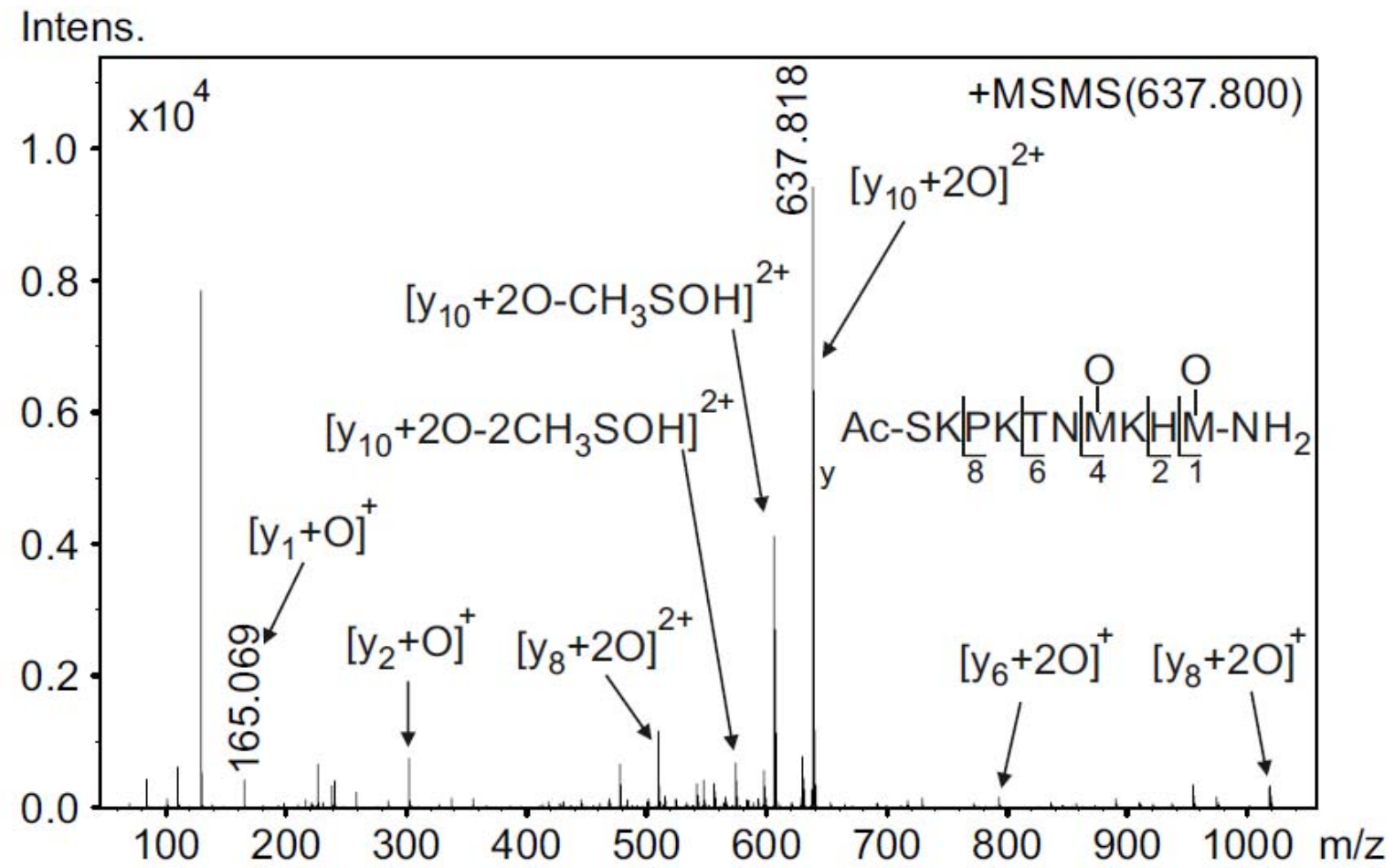

Figure 7 
Intens.

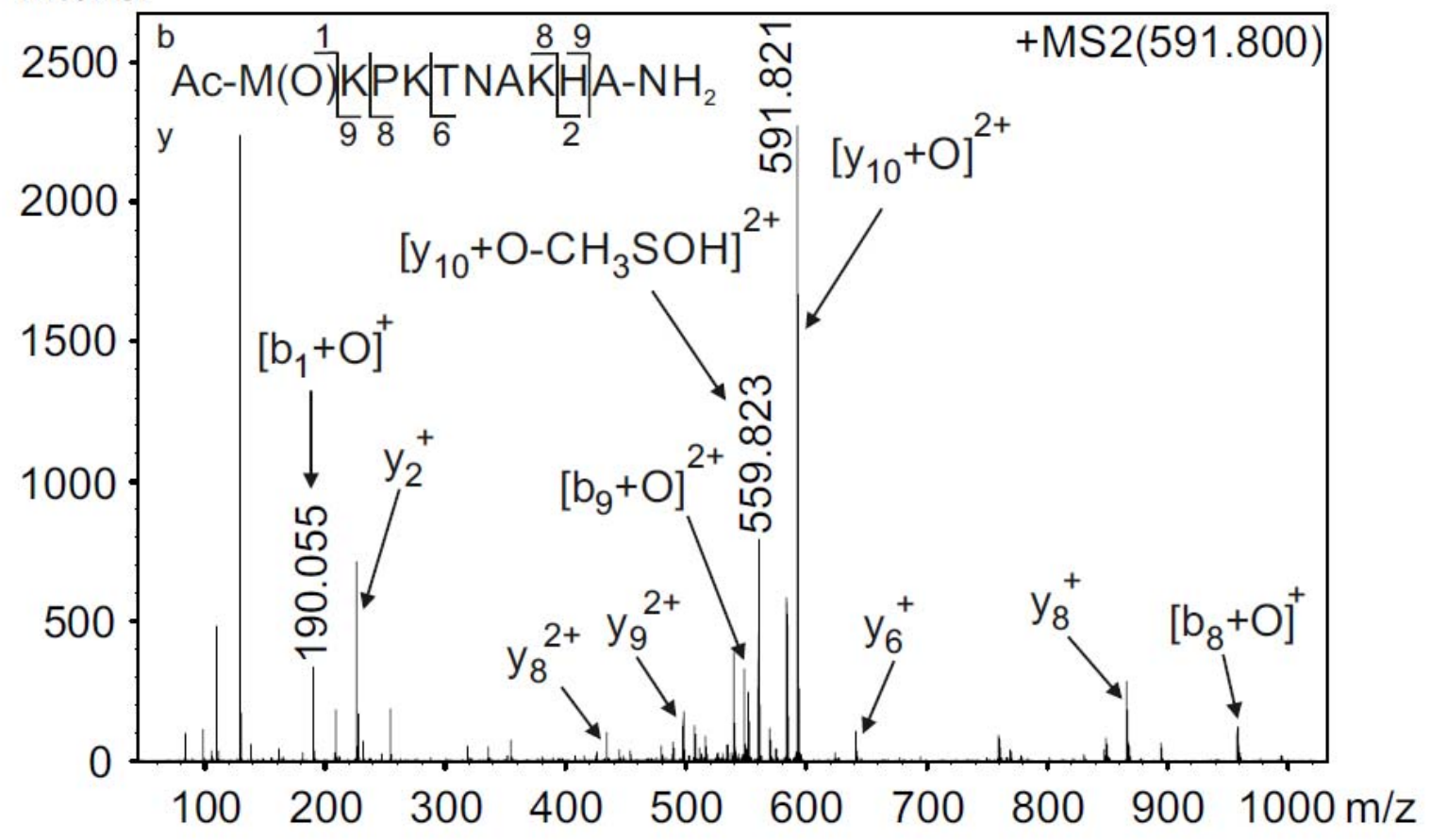

Figure 8 